\title{
Efforts to Increase Capacity of Self Adjustment of The Situation of Learning Through Group Discussion Technique
}

\author{
Mubarak Al Qarni \\ Study Program of Guidance and Counselling \\ Faculty of Teacher Training and Education \\ Universitas Lambung Mangkurat \\ Banjarmasin, Indonesia \\ mubarak.alqarni@ulm.ac.id
}

\begin{abstract}
The purpose of the research is to improve the ability of Adjustment to the Situation Learning through group discussion techniques. The general objective of this study is to describe the activities of counselors (researchers), as well as improving student's adjustment to the learning situation. This study uses a Class Action Research. The population in this study is a class XI student of SMAN 5 Banjarmasin with the number of students of class XI total of as many as 308 students. The sample in this research is class II XI IPS SMAN 5 Banjarmasin taken by a representative, or a small part of the population was observed. The results showed that the activities of researchers were in the category of Very Good and the activities of FA and NMP students who were sampled were in the very active category and MR students were in the active category, while the adjustment results to the learning situation of FA and NMP students were in the very successful category and MR students are in the successful category. This indicates that the group discussion technique can improve students adjustment to the learning situation.
\end{abstract}

Keywords- adjustment of Situation Learning; group discussion

\section{INTRODUCTION}

Adjustment to the learning situation learners has different rates from one person to another. Adjustment to the learning situation will affect the learning outcomes of a learner [1]. Ref [2] adjustment of the situation of learning is the process of how people achieve balance in meeting the needs by the learning environment in schools. Another sense adjustment to a learning situation is the relationship between people involved in the learning process in schools [3]. In this case, adjustment to the situation of learning is a process where individual achieves balance and harmony in yourself and the environment, especially the school environment to create an atmosphere of learning is cool, calm,

Guidance and counseling as a means of developing the potential of learners have many kinds of services and guidance. One is the guidance service groups with technical discussion group is one guidance service groups that can be used by teacher guidance and counseling (counseling teacher) in solving a subject matter for the discussion in an honest attempt to express an opinion and the conclusion after listening to and studying, and considering the views put forward in the discussion [4]. Through group counseling services with group discussion techniques, learners are honest courage to express opinions to solve problems and obtain conclusions a topic discussed in the group.

The survey results conducted by researchers at the class XI IPS II SMA Negeri 5 Banjarmasin indicate that adjustment to the learning situation is not good. Indications adjustment to the learning situation is not good that learners are not able to socialize well, no bias to cooperate in a group, do not dare to express an opinion and not be able to listen to the views of others [5].

Seeing these conditions can be interpreted that the adjustment to the situation of student learning class XI IPS II SMA Negeri 5 Banjarmasin is still not good so that researchers interested in conducting action research to improve the adjustment to the situation of the learner through group counseling services with group discussion technique. This study aims to improve the adjustment to the situation of the learner through guidance service groups with technical discussion groups, in particular the purpose of this study were (1) know the description of activity counselor (researcher), (2) know the description of activity of students, (3) determine the increase adjustment to the learning situation of students in SMA Negeri 5 Banjarmasin.

\section{METHOD}

This study uses a Class Action Research. This method is also known as an artistic method, because the research process is more art (less patterned), and is referred to as an interpretive method for more research data regarding the interpretation of the data found in the field [6]. Action research is a scientific activity conducted his class with road designing, implementing, observing, and reflecting actions through several cycles of a collaborative and participative aiming to correct or improve the quality of classroom learning process [7]. Subjects in this study were drawn from the population of students of class XI SMAN 5 Banjarmasin with the number of 
students of class XI total of as many as 308 students. The sample in this research is class II XI IPS SMAN 5 Banjarmasin taken by a representative, or a small part of the population was observed [8]. The object of this study is a tutoring service activity groups using group discussions to improve adaptation to the learning situation. Ref [9] adjustment can be enhanced through group counseling services. Preliminary data on the objective conditions in the school study obtained from observations and interviews. Researchers collecting data through observation of classroom study and interviews with students, teachers and coordinators teacher BK. Researchers collecting data through observation of classroom study and interviews with students, teachers and coordinators teacher BK.

Implementation engineering group discussions conducted in a cycle of action consists of four stages, namely: (1) planning, (2) action, (3) observation (observation), and (4) the reflection which in turn might be followed by the cycle of spiraling next [10].

\section{RESULTS AND DISCUSSION}

The survey results are conducted by researchers at the class XI IPS II SMA Negeri 5 Banjarmasin; indicating adjustment to a learning situation is not good. Through group counseling services using group discussion techniques, learners are invited to be able to socialize well, can work together in groups, dared to express an opinion and being able to listen to the views of others.

Results were taken after the implementation of the class action. In the implementation of this action research with the data obtained about the resulting increase in the adaptation to the students' learning situation after group guidance services using group discussion techniques in cycle I and II, the first and second meetings.

In cycle, I and II, the general activities of the researcher during the provision of services by using the techniques of discussion groups are observed by a school counselor. At the first meeting of the first cycle of the researchers obtained a score of 28 , with a percentage of $58.33 \%$ in the category quite well and at a second meeting, I cycle given a score of 33 with a percentage of $68.75 \%$ in both categories. At the first meeting of the second cycle, researchers obtained a score of 39 with a percentage of $81.25 \%$ in both categories, and the second meeting of the second cycle researchers obtained a score of 45 with a percentage of $93.75 \%$ categories very well. The increased activity of a counselor at a meeting of the first and second cycle I can be seen in the following figure:

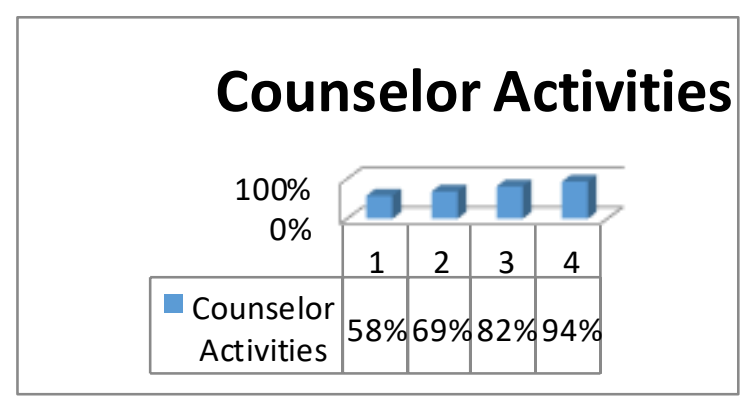

Fig. 1. Diagram Activities Counselors Cycle I and II

Based on the results of observations in the first cycle in general the activities of students are included in a sufficient category where at the first meeting students are still less active in service activities with a total score of 18 and a percentage of $37.50 \%$, but in cycle II students get a total score of 26 and a percentage of $54.16 \%$. In the cycle, II activity of students get a total score of 33 with a percentage of $68.75 \%$ in the active category, and the second meeting increased to 41 with the percentage $85.41 \%$ in a very active category can be seen in the table and figure below:

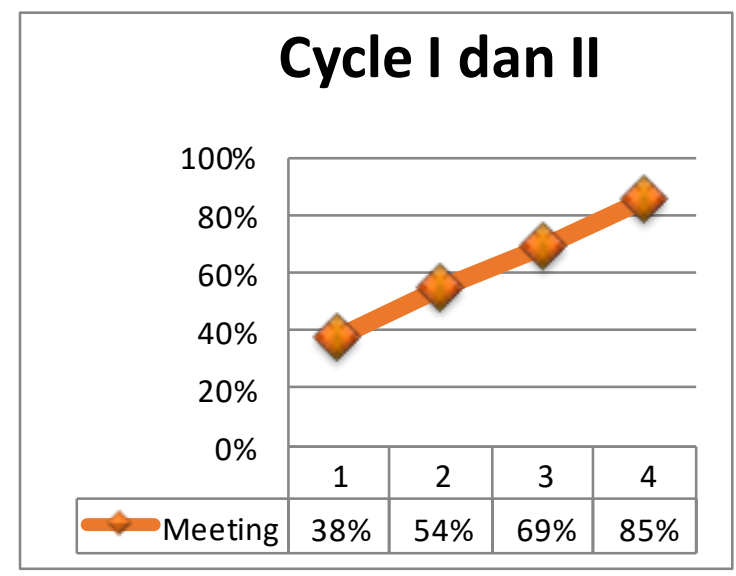

Fig. 2. Student Activity Cycle I and II

Based on observations on the first and second cycles of the first meeting until the second meeting of the general results of the adaptation to the teaching situation in the first cycle in the category of less successful and the second cycle in a very successful category can be seen in the figure 3: 


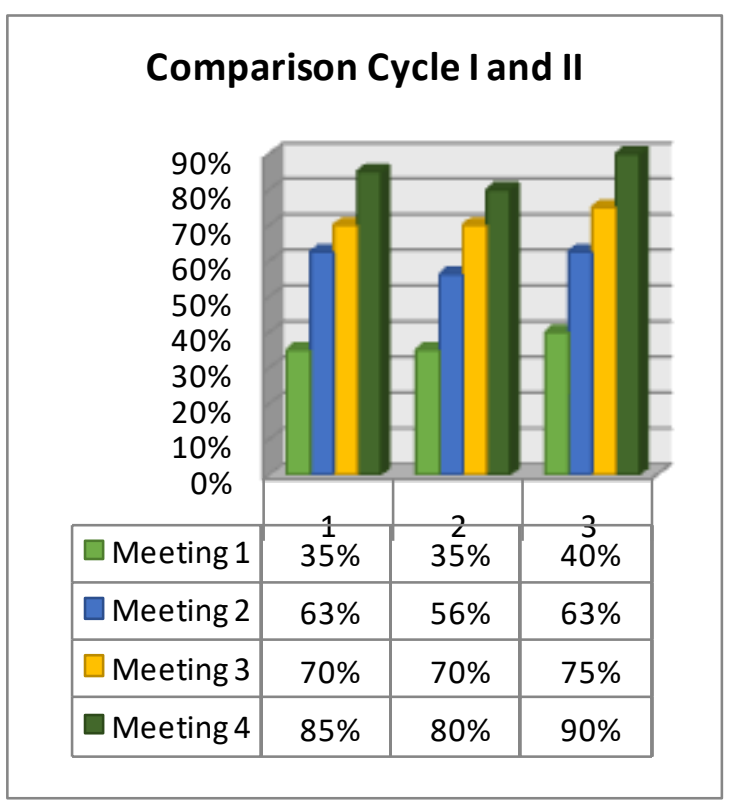

Fig. 3. Results of adjustment to the learning situation

\section{CONCLUSION}

In general, this study concludes that the activities of researchers are in the category of Very Good and the activities of FA and NMP students who are sampled are in the very active category and MR students are in the active category, while the adjustment results to the learning situation of FA and NMP students are in the category very successful and MR students are in the successful category. This indicates that the group discussion technique can improve students' adjustment to the learning situation.

\section{REFERENCES}

[1] M. Ali and M. Asrori, Psikologi remaja perkembangan peserta didik. Jakarta: Bumi Aksara, 2012.

[2] S. Hartina, Pengembangan peserta didik. Bandung: Refika Aditama, 2010

[3] Suriansyah, Strategi pembelaiaran. Jakarta: Raja Grafindo Persada, 2014.

[4] Prayitno and E. Amti, Dasar-dasar bimbingan konseling. Jakarta: Asdi Mahasatya, 2009.

[5] M. Thobroni and A. Mustofa, Belajar dan pembelajaran. Yogyakarta: Arr-Ruzz Media, 2013.

[6] Sugiyono, Metode penelitian kuantitatif kualitatif dan R \& D. Bandung: Alfabeta, 2013.

[7] Kunandar, Langkah mudah penelitian tindakan kelas sebagai pengembangan profesi guru. Jakarta: PT Rajawali Press, 2012.

[8] Iskandar, Metodologi penelitian pendidikan dan sosial. Jakarta: Referensi, 2013.

[9] S. Lestari, "Meningkatkan penyesuaian diri terhadap program keahlian melalui layanan bimbingan kelompok pada siswa kelas x smk negeri 1 purbalingga," 2013. [Online]. Available: http://lib.unnes.ac.id/17338/1/1301409063.pdf. [Accessed 2009 2018].

[10] Ekawarna, Penelitian tindakan kelas. Jakarta: Referensi GP Press Group, 2013. 